\title{
Determinants of electricity consumption based on the NUTS 2 regions of Turkey: A panel data approach
}

\author{
Semra Türkan \\ (corresponding author) \\ Hacettepe University \\ Faculty of Science, \\ Turkey \\ E-mail: sturkan@hacettepe.edu.tr \\ Gamze Ozel \\ Hacettepe University \\ Faculty of Science, \\ Turkey \\ E-mail: \\ gamzeozl@hacettepe.edu.tr \\ Keywords: \\ electricity consumption, \\ panel regression, \\ fixed effects model, \\ Wald test \\ Previous studies have focused on the relation- \\ ship in recent years between electricity con- \\ sumption and socio-economic indicators, but \\ little attention has been paid to regional dif- \\ ferences in Turkey. This study determines the \\ electricity consumption indicators of Turkey \\ based on the Nomenclature of Territorial \\ Units for Statistics (NUTS 2) regions during \\ 2004-2011. To achieve this objective, panel \\ data regression models, including socio- \\ economic indicators (gross value added, and \\ import and export amounts) were developed. \\ The study represents the first instance of re- \\ gional knowledge for electricity consumption \\ using the panel data approach. The empirical \\ results show that electricity consumption for \\ the NUTS 2 regions can be modelled using \\ fixed effects models with standard errors ob- \\ tained by the White estimator. The study re- \\ veals that regional development leads to in- \\ creases in electricity consumption. Further- \\ more, electricity demand has grown impres- \\ sively in line with regional economic devel- \\ opments in Turkey.
}

\section{Introduction}

Electricity is a key factor in improving quality of life and economic and social progress. Governments in developed and developing countries mainly pay attention to the determinants that increase electricity consumption. Hence, the policies that will increase electricity production or decrease electricity consumption are of prime importance (Kavaklioglu et al. 2009).

Electricity is among the most important energy resources in Turkey. Electricity is used in all areas of daily life, especially industrial production, the housing sector, agriculture, lighting, and heating. Although electricity consumption in the industry sectors has increased, its portion of total electricity consumption declined after the 1990s. The rate of electricity consumption in other sectors remained the same between 1970 and 2012. Following the restructuring of the electricity sector in the 1990s, both the consumption and the generation of electricity have expanded. Fig-

Regional Statistics, Vol. 9. No. 1. 2019: 120-134; DOI: 10.15196/RS090105 
Determinants of electricity consumption based on the NUTS 2 regions of Turkey: A panel data approach

ure 1 shows the percentage of electricity consumption in each sector between 1970 and 2012. Figure 2 shows the sectoral distribution of the electricity consumption of Turkey in 2012.

Figure 1

Percentage of electricity consumption by sector

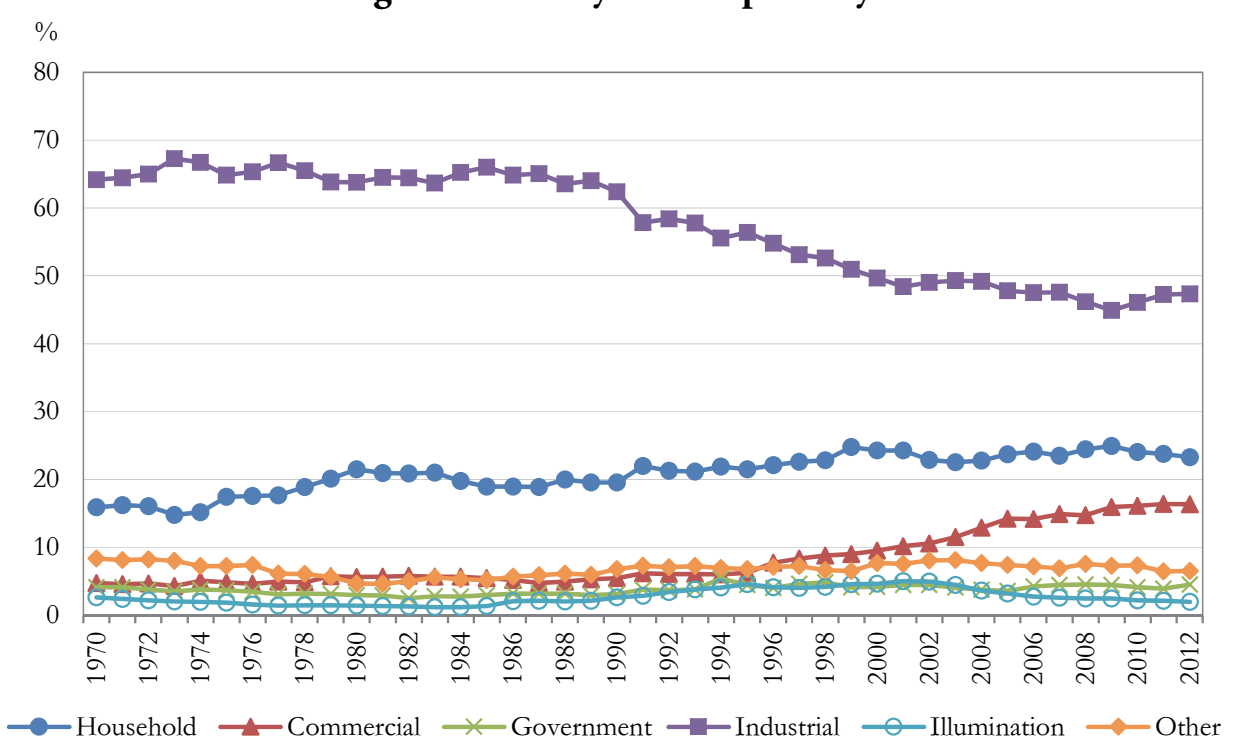

Distribution of electricity consumption by sector, 2012

Figure 2

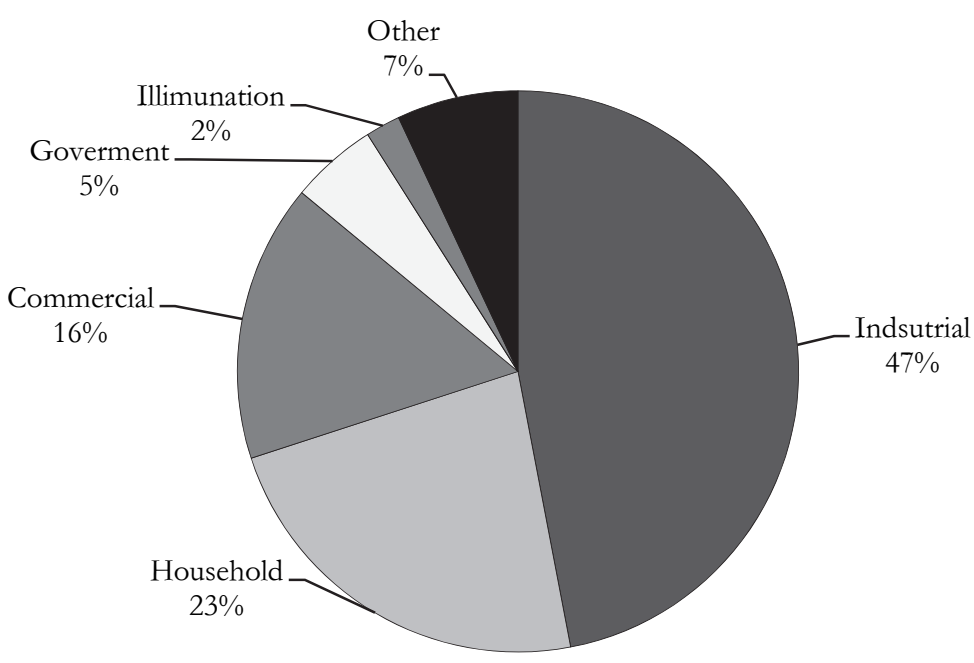

Source: TEDAS (2012)

Regional Statistics, Vol. 9. No. 1. 2019: 120-134; DOI: 10.15196/RS090105 
As observed in Figure 2, the industry sector has the largest portion of electricity consumption in Turkey, consuming $47 \%$ of the produced electricity. In Turkey, household consumption is second at $23 \%$, reflecting the housing sector's second largest share of electricity consumption at 1,169 GWh in 1970 and 44,832 GWh in 2012. Lighting is the sector with the lowest electricity consumption at $2 \%$ (TEDAS 2012).

Turkey's electricity demand has rapidly increased during the past few years, and future increases are likely to continue given the country's rapid economic growth, young population, and other worldwide energy developments. According to the International Energy Agency (IEA), energy consumption will continue to increase at an approximate annual growth rate of 4.5\% from 2015 to 2030. Given Turkey's limited energy resources, the country depends on imported energy sources for electricity production.

Turkey's energy sources include hydropower, geothermal, lignite, hard coal, oil, natural gas, biomass (wood, animal, and plant wastes), solar, and wind energy. Nuclear energy has not yet been included in the country's energy sources (Erdogdu 2010), but Turkey will begin to utilize nuclear energy to produce electricity in the next few decades. Most of the electricity is generated using fossil fuel sources. Fossil fuels contributed approximately $60 \%$ of Turkey's total energy consumption in the 1970s (Kentel-Alp 2013). This ratio reached $88 \%$ in 2011, with natural gas (32\%) in first place, followed by coal (29\%) and oil (27\%) (Uzlu et al. 2009). However, fossil fuel reserves in Turkey are quite limited. Turkey's energy policy mainly focuses on improvements in sufficient and secure energy sources. To address the dependence on imported fossil fuels and to take the necessary precautions, Turkey's future electricity consumption should be known realistically. Thus, a critical factor for Turkey's energy policy is an accurate assessment of its future energy needs.

The relationship between energy consumption and economic indicators is analysed in several studies. In these studies, energy or electricity consumption was generally used as a dependent variable. We focus on investigating the relationship between regional economic indicators and electricity consumption for the Nomenclature of Territorial Units for Statistics (NUTS 2) regions of Turkey (Akay-Atak 2007, Jebaraj-Iniyan 2006). For regional policy, identifying the key industries within a given region, analysing their spatial and network dependencies, measuring their dependencies from weaker to stronger and knowing how to influence them to improve their economic performance are the essential steps (Jarosi 2017). Regression models, time series, neural networks, and econometric models are the most used statistical methods in modelling and forecasting of energy or electricity research. Regression models have been the most popular modelling method to determine the factors that affect and predict electricity consumption (Yumurtaci-Asmaz 2004). In particular, Zhang-Zhao (2014) used the panel data approach to estimate $\mathrm{CO}_{2}$ emissions in China. However, panel data analysis has never been used for either electricity consumption or Turkey.

Regional Statistics, Vol. 9. No. 1. 2019: 120-134; DOI: 10.15196/RS090105 
Research on predicting electricity consumption in Turkey has been conducted by the Ministry of Energy and Natural Resources (MENR) and the State Planning Organization (SPO). The MENR uses the regression model to analyse energy demand that historically has not produced reliable intermediate- to long-term results for Turkey (MENR 2014). In recent years, the Regional Competitiveness Operational Programme (RCOP) has been a basic document for the implementation of the Instrument for Pre-Accession in Turkey. The goal of the programme is to promote Turkey in its preparation for membership to the European Union (EU); this is part of the Regional Competitiveness Operational Programme framework to increase the competitiveness of the Turkish economy when converging with that of the EU and to reduce regional socio-economic differences. To achieve these aims, the RCOP focuses on resources in a limited number of sectors, regions, and priorities for which the impact of programmes and contributions will be greatest (Republic of Turkey Ministry of Industry and Trade Report 2007). Hence, the regional statistics and analyses are important steps in this programme. This statement has motivated the present research to study a different modelling technique for Turkey's electricity consumption on the basis of regional economic indicators, such as gross value added (GVA) per capita, imports (IM), and exports (EX). Our study focuses on modelling electricity consumption for NUTS 2 regions of Turkey, whereas most previous studies and analyses focused on modelling energy or electricity consumption for Turkey as a whole and not at the regional level. Furthermore, no study on the regional analysis of electricity consumption for Turkey used a panel data regression analysis.

\section{Literature review}

Prominent studies on electricity demand/consumption from literature search are listed in Table 1. These studies generally utilized diverse co-integration and causality tests to examine the relationship between electricity consumption and economic indicators. In these studies, separate findings based on the country/country group are obtained (Glasure-Lee 1997). In our study, we investigate the determinants of electricity consumption at the regional level. For this reason, socio-economic indicators, such as GVA per capita, imports, and exports, are determined by considering previous studies.

Regional Statistics, Vol. 9. No. 1. 2019: 120-134; DOI: 10.15196/RS090105 
Table 1

Prominent research on electricity demand/consumption for different countries

\begin{tabular}{|c|c|c|c|c|}
\hline Research & Method & Indicator & $\begin{array}{l}\text { Dependent } \\
\text { variable }\end{array}$ & Country \\
\hline $\begin{array}{l}\text { Glasure-Lee } \\
\text { (1997) }\end{array}$ & Co-integration & GDP & $\begin{array}{l}\text { Electricity } \\
\text { consumption }\end{array}$ & South Korea \\
\hline Shiu-Lam (2004) & Co-integration & GDP & $\begin{array}{l}\text { Electricity } \\
\text { consumption }\end{array}$ & China \\
\hline Bianco et al. (2009) & Regression & $\begin{array}{l}\text { Population, GDP } \\
\text { per capita }\end{array}$ & $\begin{array}{l}\text { Electricity } \\
\text { consumption }\end{array}$ & Italy \\
\hline $\begin{array}{l}\text { Mohamed-Bodger } \\
\text { (2005) }\end{array}$ & Regression & $\begin{array}{l}\text { GDP, average price of } \\
\text { electricity, population }\end{array}$ & $\begin{array}{l}\text { Electricity } \\
\text { consumption }\end{array}$ & New Zealand \\
\hline Pao (2006) & Artificial neural network & $\begin{array}{c}\text { National income, GDP, } \\
\text { consumer price index }\end{array}$ & $\begin{array}{l}\text { Electricity } \\
\text { consumption }\end{array}$ & Taiwan \\
\hline Zhou et al. (2006) & $\begin{array}{l}\text { Trigonometric grey } \\
\text { prediction }\end{array}$ & - & $\begin{array}{c}\text { Electricity } \\
\text { demand }\end{array}$ & China \\
\hline Bianco et al. (2010) & $\begin{array}{l}\text { Holt-Winters exponen- } \\
\text { tial smoothing, Trigo- } \\
\text { nometric grey model } \\
\text { with rolling mechanism }\end{array}$ & - & $\begin{array}{l}\text { Electricity } \\
\text { consumption }\end{array}$ & Romania \\
\hline $\begin{array}{l}\text { Zhang-Zhao } \\
\text { (2014) }\end{array}$ & Panel regression & $\begin{array}{l}\text { GDP per capita, } \\
\text { Gini-coefficient, } \\
\text { energy intensity, share } \\
\text { of industry sector, } \\
\text { urbanization }\end{array}$ & $\mathrm{CO}_{2}$ emissions & China \\
\hline
\end{tabular}

As observed in Table 1, seven of these studies are related to electricity consumption. Only one study on electricity consumption used the panel data approach. The use of the panel data approach for modelling has attracted attention in recent decades. Hence, this study purposes to determine the indicators of regional electricity consumption for Turkey based on NUTS 2 regions through a panel data regression. In addition, few studies examined the relationship between economic indicators and electricity consumption in Turkey using different methods and approaches. A summary of the methods and variables used in these studies is presented in Table 2.

Research on forecasting energy demand or consumption for Turkey began in the 1960s. Regression analysis is used by the SPO for energy forecasting. Since 1984, several econometric methods have been used for energy demand or consumption forecasts (Kankal et al. 2011). Some studies on energy demand or consumption for Turkey are presented in Table 2 . 
Table 2

Literature search on electricity consumption or demand in Turkey

\begin{tabular}{|c|c|c|c|}
\hline Study & Methodology & $\begin{array}{l}\text { Independent } \\
\text { variable }\end{array}$ & $\begin{array}{l}\text { Dependent } \\
\text { variable }\end{array}$ \\
\hline $\begin{array}{l}\text { Yumurtaci-Asmaz } \\
\text { (2004) }\end{array}$ & Regression & $\begin{array}{l}\text { Population, energy } \\
\text { consumption, increase } \\
\text { rates per capita }\end{array}$ & $\begin{array}{c}\text { Electricity } \\
\text { demand }\end{array}$ \\
\hline Ozturk et al. (2005) & Genetic algorithm approach & - & $\begin{array}{l}\text { Electricity } \\
\text { demand }\end{array}$ \\
\hline Hamzaçebi (2007) & Artificial neural networks & $\begin{array}{l}\text { Transportation, agriculture, } \\
\text { residence, industry sector }\end{array}$ & $\begin{array}{l}\text { Electricity } \\
\text { consumption }\end{array}$ \\
\hline Kavaklioglu et al. (2009) & Artificial neural networks & $\begin{array}{l}\text { Population, GNP, import, } \\
\text { export }\end{array}$ & $\begin{array}{l}\text { Electricity } \\
\text { consumption }\end{array}$ \\
\hline Erdogdu (2007) & $\begin{array}{l}\text { Co-integration analysis, } \\
\text { ARIMA }\end{array}$ & - & $\begin{array}{l}\text { Electricity } \\
\text { demand }\end{array}$ \\
\hline Aslan (2014) & $\begin{array}{l}\text { Granger } \\
\text { causality test }\end{array}$ & - & $\begin{array}{l}\text { Electricity } \\
\text { consumption }\end{array}$ \\
\hline Nazlioglu et al. (2014) & $\begin{array}{l}\text { Co-integration, linear and } \\
\text { nonlinear Granger } \\
\text { causality test }\end{array}$ & - & $\begin{array}{l}\text { Electricity } \\
\text { consumption }\end{array}$ \\
\hline
\end{tabular}

As observed in Table 2, the panel data approach has never been used to analyse electricity consumption in Turkey.

\section{Methodology}

Panel data, also called cross-sectional time series data, are repeated observations of the same set of cross-section units. A panel dataset should have data on $n$ cases over $t$ periods for a total of $(n \times t)$ observations.

\section{Pooled ordinary least square}

The simplest case of using longitudinal data arises from ignoring the panel structure of the data. The model can be written as

$$
y=X \beta+e,
$$

where $e \sim N\left(0, \sigma^{2}\right)$ is assumed to be identically independent distributed (iid) and, for a given $X$, the observations have no serial correlation and the errors are not heteroskedastic. The pooled ordinary least square (OLS) approach might be reasonable when the cross-sectional sample sizes are too small (Cancado 2005).

The pooled OLS estimator is considered a starting point for the empirical analyses. Two other models exist for an analysis of panel data in addition to the pooled OLS: the fixed effects and random effects models.

Regional Statistics, Vol. 9. No. 1. 2019: 120-134; DOI: 10.15196/RS090105 


\section{Fixed effects and random effects models}

Consider the general panel data model

$$
y_{i t}=X_{i t} \beta+\varepsilon_{i t},
$$

where the error term $\varepsilon_{i t}=a_{i}+\eta_{i t}$ consists of individual specific effect $a_{i}$ and common stochastic error term $\eta_{i \text { t }}$ and $\eta_{i t}$ is assumed to be uncorrelated with $X_{i \text { t }}$

The assumption that distinguishes the fixed effects model from the random effects model is that $a_{i}$ may or may not be correlated with the set of explanatory variables, $X_{i t} a_{i}$ is uncorrelated with $X_{i t}$ in the random effects model and is correlated with $X_{i t}$ in the fixed effects model.

Two basic tests can determine which panel analysis should be used: the Lagrange multiplier (LM) and Hausman specification test. The LM, proposed by BreuschPagan (1980), is calculated to determine whether a pooled OLS regression or random effects model should be used. The LM test is easy to compute because it only requires pooled OLS residuals and is given by

$$
L M=\frac{N T}{2(T-1)}\left[\frac{\sum_{i=1}^{N}\left(\sum_{t=1}^{T} \widehat{\varepsilon}_{i t}\right)^{2}}{\sum_{i=1}^{N} \sum_{t=1}^{T} \widehat{\varepsilon}_{i t}^{2}}-1\right]^{2},
$$

where $N$ is the number of cases and $T$ is the number of periods.

The LM is distributed as $X^{2}$ with one degree of freedom. If the LM exceeds the critical value, we conclude that the pooled OLS method is inappropriate and the random effects model is preferable. The Hausman specification test selects between the fixed effects and random effects models under the null hypothesis that the individual effects are uncorrelated with the other regressors in the model. If they are correlated $\left(H_{0}\right.$ is rejected), a random effects model produces biased estimators, violating one of the Gauss-Markov assumptions; hence, a fixed effects model is preferred. Note that under the null hypothesis, the Hausman statistic is asymptotically distributed as $X^{2}$ with $k$ degrees of freedom (Srivasan 2012).

\section{Modelling of determinants of electricity consumption for NUTS 2 regions}

\section{Data description and modelling}

In this study, electricity consumption for the NUTS 2 regions of Turkey is modelled as a function of socio-economic indicators. All of the data are obtained from TURKSTAT (http://www.turkstat.gov.tr) under titled statistics by theme. For this reason, we used a balanced panel dataset, which means that the number of periods $T$ is the same for all individuals $i$ of the 26 NUTS 2 regions of Turkey during 2004-2011. The list of NUTS 2 regions is provided in the Appendix. Figure 3 indicates the regional distribution of electricity consumption.

Regional Statistics, Vol. 9. No. 1. 2019: 120-134; DOI: 10.15196/RS090105 
Map of electricity consumption by the NUTS 2 regions of Turkey, 2011

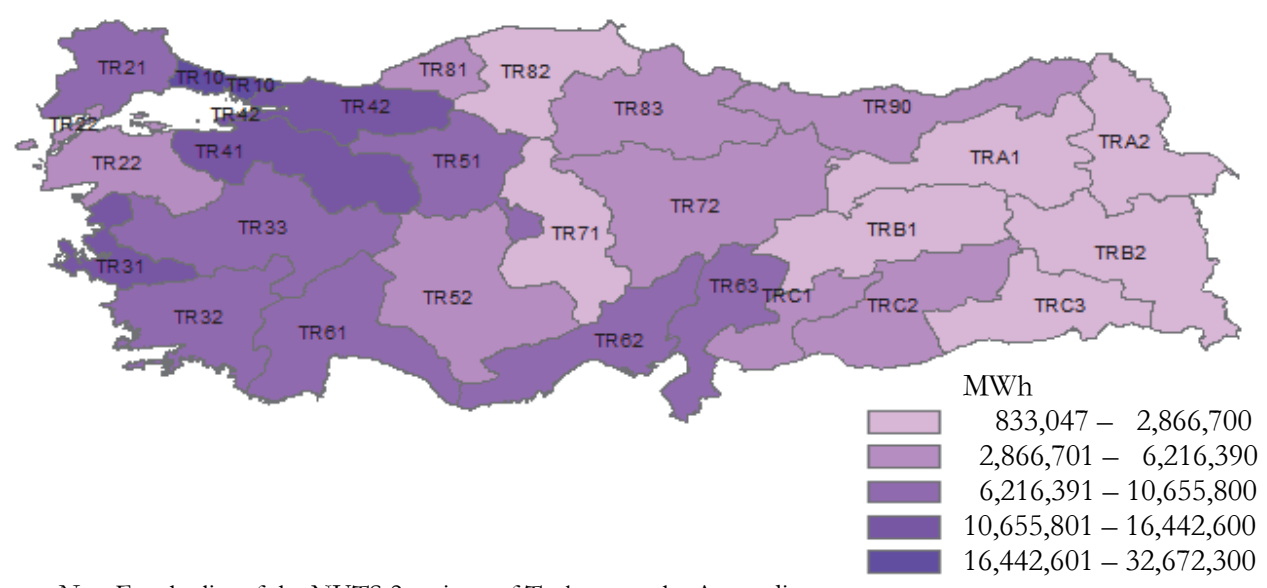

Note: For the list of the NUTS 2 regions of Turkey, see the Appendix.

Regarding the regional distribution of electricity consumption, Figure 3 indicates that the first five regions with the highest electricity consumption (the darkest regions) are TR10, TR41, TR31, TR42, and TR63. TRA2, TR82, and TRA1 are regions with the lowest electricity consumption. As is known, energy provides input for each sector of the economy. As electricity is an indispensable input in industrial production processes, energy consumption has increased. For this reason, the import and export amounts have a significant effect on electricity consumption. Turkish manufacturers are mainly located in TR10, TR41, and TR31. In recent years, TR63 has become a main new industrial district in Turkey given that electricity consumption has increased in this region.

The data used in this study are obtained from the Turkish Statistical Institute. Socio-economic indicators, such as the GVA/pop, imports, and exports - similar to precedent studies - are considered to determine electricity consumption. In this study, we examine electricity consumption for the NUTS 2 regions because the variables are determined to reflect the regional structure. Hence, we have used GVA/pop and not GDP as the regional development indicator. GVA/pop is a measure in economics of the value of goods and services produced in an area, industry, or sector of the economy. GVA/pop, one of the major macroeconomic indices in regional development, is an indicator of economic growth. An increased GVA/pop means improved living standards in a region and, thus, increased electricity consumption. Import and export amounts for Turkey are related to manufacturing processes; therefore, they strongly affect the amount of electricity consumption (Kankal et al. 2011). Electricity consumption is considered to be a dependent varia-

Regional Statistics, Vol. 9. No. 1. 2019: 120-134; DOI: 10.15196/RS090105 
ble, whereas GVA/pop, import amount (IM), and export amount (EX) are considered to be independent variables. Table 3 lists the definition of the variables.

Table 3

Definition of variables and acronyms

\begin{tabular}{l|l|l}
\hline \multicolumn{1}{c|}{ Variable } & \multicolumn{1}{c}{ Units of measure } & \multicolumn{1}{c}{ Definition } \\
\hline Total electricity consumption & MWh & Total electricity consumption \\
Gross value added per capita & 1,000 Turkish Lira & GVA divided by population \\
Imports & 1,000 USD & Imports by economic activities \\
Exports & 1,000 USD & Exports by economic activities
\end{tabular}

Figure 4 reflects the electricity consumption, GVA per capita, import amount, and export amount of Turkey from 2004 to 2011.

Figure 4

\section{Electricity consumption and corresponding indicators in Turkey}
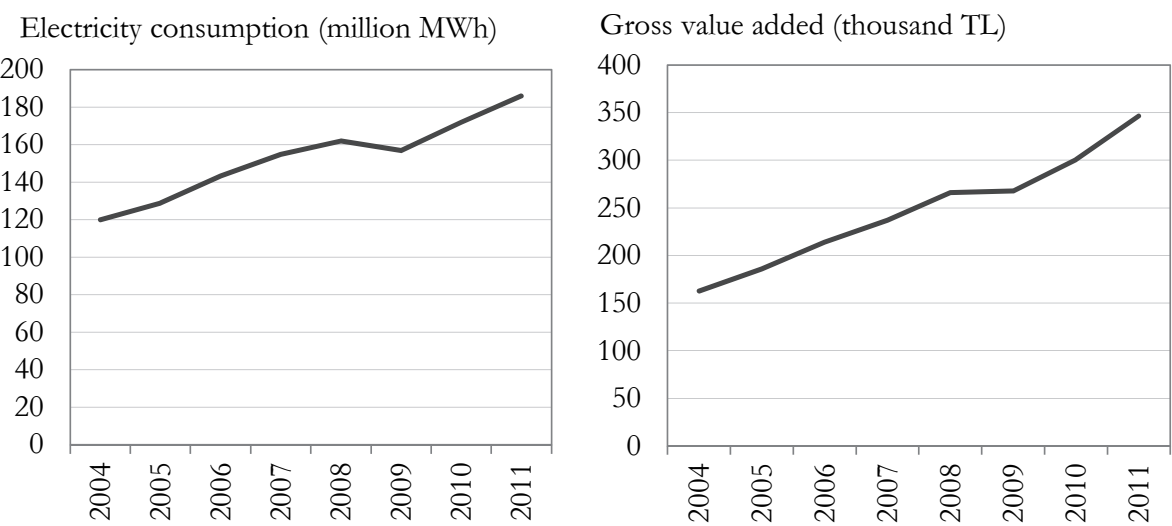

Exports (billion USD)

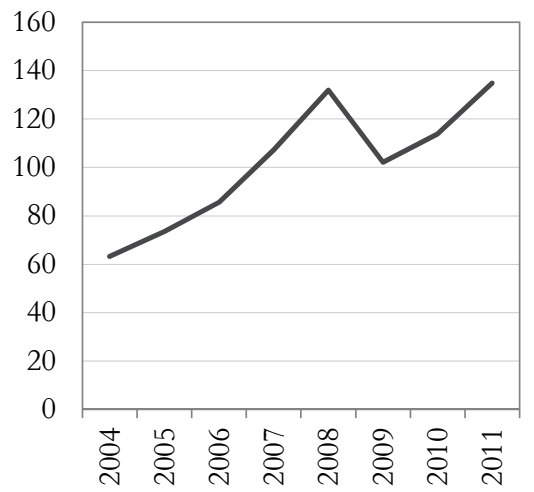

Imports (billion USD)

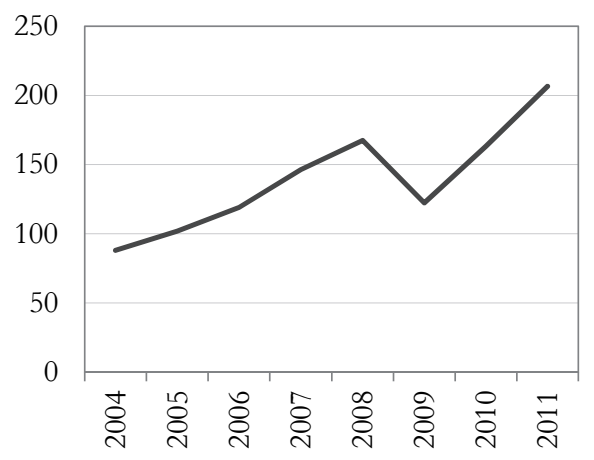

Regional Statistics, Vol. 9. No. 1. 2019: 120-134; DOI: 10.15196/RS090105 
Figure 4 indicates that all of these variables in Turkey increased gradually until 2008. Because of the global crisis in 2009, imports and exports decreased aggressively, whereas electricity consumption and GVA per capita decreased slightly. After 2009 , all variables steadily increased. Electricity consumption and GVA per capita in all regions indicated similar tendencies, varying slightly during 2004 and 2011.

To examine the determinants of electricity consumption in Turkey, the panel data approach has been applied. The panel $\log -\log$ form of the estimable regression model can be written as follows:

$\ln E C_{i t}=\beta_{0}+\beta_{1} \ln (G V A / p o p)_{i t}+\beta_{2} \operatorname{lnI} M_{i t}+\beta_{3} \ln E X_{i t}+\varepsilon_{i t}$.

The natural log form measures the GVA/pop elasticity, import elasticity, and export elasticity of electricity consumption. $\varepsilon_{i t}$ is an error term that is assumed to be independently and normally distributed.

\section{Empirical results}

First, we need to determine the panel data techniques that should be used. Before the analysis, multicollinearity is controlled by variance inflation factor (VIF) values. The VIF values of GVA/pop, import, and export are found to be 2.0946, 5.7096, and 6.6574, respectively. No multicollinearity existed because all VIF values are less than 10. For this reason, the LM test is used to determine whether the pooled OLS regression or the random effects model should be selected. The calculated LM test value (LM test value $=480.61)$ exceeds the tabulated chi-squared value $\left(X_{1, a=0.05}=3.841\right)$, leading us to conclude that the random effects model is more appropriate than pooled OLS. Next, we need to choose between the fixed and random effects models. For this reason, we conducted the Hausman specification test, whose null hypothesis is that the preferred model is the random effects model. The Hausman test statistic is defined as:

$$
H S=\left(\hat{\beta}_{F E}-\hat{\beta}_{R E}\right)^{\prime}\left(\operatorname{Var}\left(\hat{\beta}_{F E}-\hat{\beta}_{R E}\right)\right)^{-1}\left(\hat{\beta}_{F E}-\hat{\beta}_{R E}\right),
$$

where $\beta_{S E}$ is the estimated parameter vector of the fixed effects model and $\beta_{R E}$ is the estimated parameter vector of the random effects model. The results of the Hausman test revealed that the random effects model is not appropriate and that the fixed effects specification is preferred $(p=0.000<0.050)$.

Before estimating the fixed effects model, group-wise heteroskedasticity, autocorrelation, and cross-sectional independence are investigated (Zhang-Zhao 2014). The modified Wald test in the fixed effects regression model is used to test groupwise heteroskedasticity. A Wooldridge test is used to test serial correlation. The Pesaran cross-sectional dependence (CD) test is used to determine whether the residuals are correlated across entities. The results of the tests are presented in Table 4.

Regional Statistics, Vol. 9. No. 1. 2019: 120-134; DOI: 10.15196/RS090105 
Test results

\begin{tabular}{l|c|c}
\hline & Test value & $p$-value \\
\hline Modified Wald test & 1537.25 & $0.000^{*}$ \\
Wooldridge test & 0.255 & 0.618 \\
Pesaran CD test & 0.783 & 0.434
\end{tabular}

* Means significant at the $5 \%$ confidence level.

As Table 4 indicates, the null hypotheses 'There is no serial correlation' and 'Residuals are not correlated' are not rejected, respectively $(p=0.618>0.050)$ and $p=0.434>0.050$ Therefore, no autocorrelation and cross-sectional dependence exist in the data. However, the null hypothesis 'There is no heteroskedasticity' is rejected $p=0.000<0.050$ ), indicating that heteroskedasticity exists.

Relying on 'robust' standard errors is common to ensure a valid statistical inference when some of the underlying regression model's assumptions are violated. One of the most popular of these alternative covariance matrix estimators was developed by Huber (1967), Eicker (1967), and White (1980). Standard errors, which are obtained with the assistance of the White estimator, are consistent even if the residuals have heteroskedasticity. As group-wise heteroskedasticity may exist within the dataset, the White estimator is used to determine more reliable estimations given violations of the classic hypothesis (Hoechle 2007). The results of the fixed effects model (FE) and the White estimator are provided in Table 5.

Table 5

\section{Panel estimation results}

\begin{tabular}{ll|r|r}
\hline & & Fixed effect & White estimator \\
\hline GVA/pop & & $0.5324^{*}$ & $0.5324^{*}$ \\
& & $(0.0431)$ & $(0.00746)$ \\
$\mathrm{IM}$ & 0.0136 & 0.0136 \\
$\mathrm{EX}$ & $(0.0214)$ & $(0.0311)$ \\
& & 0.035 & 0.035 \\
Constant & & $(0.0236)$ & $(0.0324)$ \\
& & $9.724^{*}$ & $9.724^{*}$ \\
$\mathrm{R}^{2}$ & $(0.1823)$ & $(0.3499)$ \\
Hausman test & $92.93^{*}$ & 0.73 & 0.73 \\
$(p$-value $)$ & $(0.000)$ & & \\
LM test & $480.61 *$ & & \\
$(p$-value $)$ & $(0.000)$ & &
\end{tabular}

*Means significant at the $5 \%$ confidence level.

Note: Figures in parentheses are the standard errors. 
Table 5 indicates that the coefficient of GVA/pop is statistically significant at the $5 \%$ level. The coefficient of GVA/pop (0.5324) is significantly positive, implying that electricity consumption will increase when regional development is improved.

\section{Conclusion}

Turkey is strategically located at the crossroads of the world's largest oil and natural gas routes. The Turkish economy is currently among the fastest growing in the OECD and has become the $18^{\text {th }}$ largest economy in the world based on purchasing power parity. Turkey's economy is driven by strong productivity gains and robust growing private consumption, investments, and exports, and has not been hindered by reductions in government consumption and investment. Given the country's growing population and ongoing industrialization, Turkey's electricity consumption has been increasing. For these reasons, Turkey is a source of interest in the energy economics literature and has therefore been examined by numerous studies analysing the relationship between electricity demand or consumption and national income. In contrast, however, the findings are still indecisive. The recently introduced panel data approach provides a flexible and powerful tool for electricity consumption. This approach has never been used for Turkey. Therefore, the contribution of this study is to model the socio-economic indicators of electricity consumption for the NUTS 2 regions of Turkey using the panel data approach. Regional data are used because of the differences among the regions in terms of economic, social, and cultural aspects. The major conclusion of this research is that electricity consumption in the NUTS 2 regions can be modelled as a function of economic indicators using panel data regression models. This study reveals that regional economic growth affects electricity consumption, indicating that increases in economic growth increase electricity consumption. As a result of the empirical findings, we determine that electricity consumption in regions is positively affected by the region's development level. At this point, energy policies aimed at reducing electricity consumption may negatively affect the growth in the regions. This study represents an initial study that determines the economic indicators of electricity consumption at the regional level. This study has been constrained to the years from 2004 to 2011 given a lack of availability statistics. 


\section{Appendix}

\section{List of NUTS 2 regions of Turkey:}

TRA1: Bayburt, Erzincan, Erzurum

TRA2: Ağrı, Ardahan, Iğdır, Kars

TRB1: Bingöl, Elazığ, Malatya, Tunceli

TRB2: Bitlis, Hakkâri, Muş, Van

TRC1: Adiyaman, Gaziantep, Kilis

TRC2: Diyarbakır, Şanlıurfa

TRC3: Batman, Mardin, Siirt, Şırnak

TR10: İstanbul

TR21: Edirne, Kirklareli, Tekirdağ

TR22: Balıkesir, Çanakkale

TR31: İzmir

TR32: Aydın, Denizli, Muğla

TR33: Afyonkarahisar, Kütahya, Manisa, Uşak

TR41: Bilecik, Bursa, Eskişehir

TR42: Bolu, Düzce, Kocaeli, Sakarya, Yalova

TR51: Ankara

TR52: Karaman, Konya

TR61: Antalya, Burdur, Isparta

TR62: Adana, Mersin

TR63: Hatay, Kahramanmaraş, Osmaniye

TR71: Aksaray, Kırıkkale, Kırşehir, Nevşehir, Niğde

TR72: Kayseri, Sivas, Yozgat

TR81: Bartın, Karabük, Zonguldak

TR82: Çankırı, Kastamonu, Sinop

TR83: Amasya, Çorum, Samsun, Tokat

TR90: Artvin, Giresun, Gümüşhane, Ordu, Rize, Trabzon

\section{REFERENCES}

AKAY, D.-ATAK, M. (2007): Grey prediction with rolling mechanism for electricity demand forecasting of Turkey Energy 32(9): 1670-1675. https://doi.org/10.1016/j.energy.2006.11.014

AsLAN, A. (2014): Causality between electricity consumption and economic growth in Turkey: An ARDL bounds testing approach Energy Sources, Part B: Economics, Planning, and Policy 9(1): 25-31. https://doi.org/10.1080/15567241003681882

BIANCO, V.-MANCA, O.-NARDINI, S. (2009): Electricity consumption forecasting in Italy using linear regression models Energy 34(9): 1413-1421.

https://doi.org/10.1016/j.energy.2009.06.034

Regional Statistics, Vol. 9. No. 1. 2019: 120-134; DOI: 10.15196/RS090105 
Bianco, V.-Manca, O.-NARdini, S.-MineA, A. A. (2010): Analysis and forecasting of nonresidential electricity consumption in Romania Applied Energy 87(11): 3584-3590. https://doi.org/10.1016/j.apenergy.2010.05.018

Breusch, T. S.-PAGAN, A. R. (1980): The Lagrange multiplier test and its applications to model specification in econometrics The Review of Economic Studies 47(1): 239-253. https://doi.org/10.2307/2297111

Cancado, L. P. (2005): Economic Growth: Panel Data Evidence from Latin America Master of Arts Thesis, Faculty of Center for International Studies of Ohio University.

ERDOGDU, E. (2007): Electricity demand analysis using co-integration and ARIMA modelling: a case study of Turkey Energy Policy 35(2): 1129-1146. https://doi.org/10.1016/j.enpol.2006.02.013

ERdogdu, E. (2010): Natural gas demand in Turkey Applied Energy 87(1): 211-219. https://doi.org/10.1016/j.apenergy.2009.07.006

EICKER, F. (1967): Limit theorems for regressions with unequal and dependent errors In: Le Cam, L.-Neyman, J. (eds). Proceedings of the Fifth Berkeley Symposium on Mathematical Statistics and Probability pp. 59-82. University of California Press, Berkeley.

Glasure, Y. U.-LEE, A-R. (1998): Cointegration, error-correction, and the relationship between GDP and electricity: the case of South Korea and Singapore Resource and Energy Economics 20(1): 17-25. https://doi.org/10.1016/s0928-7655(96)00016-4

HAMZAÇEBI, C. (2007): Forecasting of Turkey's net electricity energy consumption on sectoral bases Energy Policy 35(3): 2009-2016. https://doi.org/10.1016/j.enpol.2006.03.014

HoECHLE, D. (2007): Robust standard errors for panel regressions with cross-sectional dependence The Stata Journal: Promoting communications on statistics and Stata 7(3): 281-312. https://doi.org/10.1177/1536867x0700700301

HuBER, P. J. (1967): The behavior of maximum likelihood estimates under non-standard conditions. In Proceedings of the Fifth Berkeley Symposium on Mathematical Statistics and Probability 1: 221-233. University of California Press, Berkeley.

JAROSI, P. (2017): Modelling Network Interdependencies of Regional Economies Using Spatial Econometric Techniques Regional Statistics 7(1):3-16. https://doi.org/10.15196/RS07101

Jebaraj, S.-InIYAN, S. (2006): A review of energy models Renewable and Sustainable Energy Reviews 10(4): 281-311. https://doi.org/10.1016/j.rser.2004.09.004

KANKAL, M.-AKPINAR, A.-KÖMÜRCÜ, M. I.-ÖZŞAHIN, T. Ş. (2011): Modeling and forecasting of Turkey's energy consumption using socio-economic and demographic variables Applied Energy 88(5): 1927-1939. https://doi.org/10.1016/j.apenergy.2010.12.005

Kavaklioglu, K.-Ceylan, H.-Ozturk, H. K.-Canyurt, O. E. (2009): Modeling and prediction of Turkey's electricity consumption using artificial neural networks Energy Conversion and Management 50(11): 2719-2727. https://doi.org/10.1016/j.enconman.2009.06.016

KENTEL, E.-AlP, E. (2013): Hydropower in Turkey: Economical, social and environmental aspects and legal challenges Environmental Science \&o Policy 31: 34-43. https://doi.org/10.1016/j.envsci.2013.02.008

Regional Statistics, Vol. 9. No. 1. 2019: 120-134; DOI: 10.15196/RS090105 
Mohamed, Z.-Bodger, P. (2005): Forecasting electricity consumption in New Zealand using economic and demographic variables Energy 30(10): 1833-1843.

https://doi.org/10.1016/j.energy.2004.08.012

NAZLIOGLU, S.-KAYHAN, S.-ADIGUZEL, U. (2014): Electricity consumption and economic growth in Turkey: co-integration, linear and nonlinear granger causality Energy Sources, Part B: Economics, Planning, and Policy 9(4): 315-324. https://doi.org/10.1080/15567249.2010.495970

Ozturk, H. K.-Ceylan, H.-Canyurt, O. E.-Hepbasli, A. (2005): Electricity estimation using genetic algorithm approach: a case study of Turkey Energy 30(7): 1003-1012. https://doi.org/10.1016/j.energy.2004.08.008

PAO, H-T. (2006): Comparing linear and nonlinear forecasts for Taiwan's electricity consumption Energy 31(12): 2129-2141. https://doi.org/10.1016/j.energy.2005.08.010

SHIU, A.-LAM, P-L. (2004): Electricity consumption and economic growth in China Energy Policy 32(1): 47-54. https://doi.org/10.1016/s0301-4215(02)00250-1

SRIVASAN, P. (2012): Determinants of equity share prices in India: a panel data approach The Romanian Journal of Economic 46: 205-228.

UZLU, E.-KANKAL, M.-AKPINAR, A.-DEDE, T. (2009): Estimates of energy consumption in Turkey using neural network s with the teaching e learning-based optimization algorithm Energy 75: 295-303 https://doi.org/10.1016/j.energy.2014.07.078

White, H. (1980): Heteroskedasticity-consistent covariance matrix estimator and a direct test for heteroskedasticity Econometrica 48(4): 817-838. https://doi.org/10.2307/1912934

YUMURTACI, Z.-ASMAZ, E. (2004): Electric energy demand of Turkey for the year 2050 Energy Source 26(12): 1157-1164. https://doi.org/10.1080/00908310490441520

ZHANG, CH.-ZHAO, W. (2014): Panel estimation for income inequality and $\mathrm{CO}_{2}$ emissions: A regional analysis in China Applied Energy 136: 382-392. https://doi.org/10.1016/j.apenergy.2014.09.048

Zhou, P.-ANG, B. W.-POH, K. L. (2006): A trigonometric grey prediction approach to forecasting electricity demand Energy 31(14): 2839-2847.

https://doi.org/10.1016/j.energy.2005.12.002

\section{INTERNET REFERENCES}

Ministry of ENERGy AND NATURAl RESOURCES (MENR 2014): Energy sources, Ankara, Turkey. http://www.enerji.gov.tr/tr/inc_enerji.php (2014). Accessed 20 April 2014.

Republic of Turkey Ministry of Industry And Trade (2017): The Regional Competitiveness Operational Programme Report, Ankara, Turkey.

http://ec.europa.eu/enlargement/pdf/turkey/ipa/tk3_regionalcompetitivenessop _2007_en.pdf. Accessed 26 May 2014.

Turkish EleCtricity Distribution COMPANy (TEDAS (2012): Energy Statistics, Ankara, Turkey. http://www.tedas.gov.tr (2012). Accessed 11 January 2014.

Regional Statistics, Vol. 9. No. 1. 2019: 120-134; DOI: 10.15196/RS090105 